\title{
Identifikasi Jenis - Jenis Hama Yang Menginvasi Tanaman Sawi Hijau (Brassica rapa var. parachinensis) Di Lahan Pertanian Stkip Kristen Wamena
}

\author{
Sepling Paling ${ }^{1}$, Inri $^{2)}$, Lipas Polona ${ }^{3)}$ \\ 1) Staf Pengajar Prodi Pendidikan Matematika STKIP Kristen Wamena, Jayawijaya, Papua \\ 2) Staf Pengajar Prodi Agroteknologi STIPER Petra Baliem Wamena, Jayawijaya, Papua \\ 3) Mahasiswa Prodi Agroteknologi STIPER Petra Baliem Wamena, Jayawijaya, Papua \\ E-mail: ${ }^{1)}$ seplinpalin@gmail.com
}

\begin{abstract}
ABSTRAK
Tanaman Sawi Hijau merupakan salah satu komoditas hortikultura yang sangat cocok untuk dibudidayakan di Wamena. Hal ini disebabkan karena kondisi alam di Wamena yang sangat sesuai dengan syarat tumbuh tanaman sawi hijau yaitu membutuhkan ketersediaan air dan sinar matahari yang cukup. Kita ketahui bahwa Wamena merupakan wilayah dataran tinggi yang berbentuk lembah sehingga curah hujan sangat tinggi dan paparan sinar matahari juga cukup tinggi. Namun demikian, dalam pembudidayaan sawi hijau tidak terhindar dari adanya hama pengganggu yang dapat mengganggu pertumbuhan dan produkifitas tanaman sawi hijau di Wamena. Untuk itu, tujuan penelitian ini dilakukan adalah untuk mengidentifikasi jenis-jenis hama yang menginvasi (menyerang) tanaman sawi hijau selama fase vegetatif sampai pada masa panen di lahan pertanian STKIP Kristen Wamena. Penelitian ini dilakukan dengan cara survei (pengamatan) pada hama-hama yang menyerang tanaman sawi hijau selama pertumbuhannya (fase vegetatif) sampai pada masa panen. Hasil penelitian menunjukkan bahwa hama yang menginvasi tanaman sawi hijau dalam penelitian ini yang berhasil ditemukan hanya ada satu yaitu Ulat Tritip (Plutella xylostella L.). Hama ditemukan dalam bentuk larva instar 2 sampai dengan 3 ditandai dengan adanya kerusakan daun dan ciri-ciri bentuk larva Plutella xylostella L. secara morfologi.
\end{abstract}

Kata Kunci: Plutella xylostella L, Hama, Sawi hijau, STKIP Kristen Wamena

\section{Pendahuluan}

Sawi Hijau (Brassica rapa var. parachinensis) yang juga dikenal dengan nama Caisin (Nazaruddin, 1999) termasuk sayuran daun dari keluarga cruciferae yang mempunyai nilai ekonomis tinggi. Tanaman sawi hijau berasal dari Tiongkok (Cina) dan Asia Timur. Di daerah Cina tanaman ini dibudidayakan sejak 2500 tahun yang lalu, dan menyebar ke daerah Filipina dan Taiwan. Masuknya sawi hijau ke Indonesia pada abad XI bersama denganlintas perdagangan jenis sayuran subtropislainnya. Daerah pusat penyebarannya antara lain di Cipanas (Bogor), Lembang Pangalengan (Rukmana, 2007). Tanaman sawi hijau memerlukan unsur hara yang cukup dan tersedia bagi pertumbuhan dan perkembangannya untuk 
menghasilkan produksi yang maksimal, khususnya pada bagian daunnya. Pupuk nitrogen berperan dalam meningkatkan pertumbuhan daun sawi hijau. Pupuk nitrogen menyebabkan daun tanaman menjadi lebih lebar, berwarna lebih hijau dan lebih berkualitas (Wahyudi, 2010).

Daun sawi hijau merupakan bahan makanan sayuran yang mengandung zat gizi yang cukup lengkap sehingga mengkonsumsi daun sawi hijau dapat mempertahankan kesehatan tubuh. Menurut Direktorat Gizi Departemen Kesehatan RI (1981) bahwa sawi hijau mengandung protein, lemak, karbohidrat, $\mathrm{Ca}, \mathrm{P}$, Fe, Vitamin A, Vitamin B, dan Vitamin C. Selain itu, mengkonsumsi tanaman sawi hijau dipercaya dapat menghilangkan rasa gatal pada tenggorokan karena batuk, menghilangkan sakit kepala, dan dapat membersihkan darah (Haryanto et al., 2003).

Kabupaten Jayawijaya merupakan lembah yang memiliki struktur tanah berwarna kehitaman dan lempung, suhu udara, curah hujan, dan paparan sinar matahari yang cukup menjadikan tanaman sawi hijau tumbuh subur di Jayawijaya. Wamena ibukota Kabupaten Jayawijaya mejadi salah satu daerah yang memiliki potensi besar untuk bercocok tanam sawi hijau. Daerah Wamena biasanya juga disebut Lembah Baliem.
Syarat tumbuh sawi hijau adalah membutuhkan air dan sinar matahari yang memadai (Drost \& Johnson, 2010) oleh karena itu, tanaman sawi sangat cocok dibudidayakan pada lahan-lahan terbuka dan berkecukupan air. Hal ini sangat sesuai dengan kondisi geografis di Wamena yang memiliki curah hujan yang cukup tinggi dan sinar matahari yang cukup. Namun demikian, pertumbuhan sawi hijau tentunya memiliki kendala dalam membudidayakannya yaitu adanya serangan hama yang dapat mengganggu pertumbuhan dan produktifitas tanaman sawi hijau.

Hama yang biasanya menyerang tanaman sawi hijau diantaranya adalah ulat Tritip/ngegat punggung berlian (Plutella xylostella L.), ulat Krop Kubis (Crocidolomia binotalis Zeller, Lepidoptera: Pyralidae) dan kumbang daun atau kumbang anjing (Phyllotretasp, Coleoptera: Chrysomelidae) (Kalshoven, 1981; Pracaya, 1999). Beberapa jenis hama lainnya menurut Wahyudi (2004) seperti ordo Coleoptera, Hemiptera (kepik-kepikan), Lepidoptera (pengorok daun), Nematoda, dan Orthoptera (belalang) yang merupakan hama sekunder.

Dengan demikian, penelitian ini dilakukan untuk mengetahui jenis-jenis hama yang menginvasi tanaman sawi hijau yang ada di 
lahan pertanian STKIP Kristen Wamena.

\section{Metode Penelitian}

Penelitian ini merupakan penelitian eksperimental dengan menggunakan metode survei atau pengamatan pada semua jenis hama yang menyerang tanaman sawi hijau yang telah ditanam di lahan pertanian STKIP Kristen Wamena.

Alat yang digunakan dalam penelitian antara lain: mikroskop binokuler, kaca pembesar (lup), pinset, kamera, stoples, botol koleksi, kain kasa, karet gelang, pisau, gunting, plakat nama, alatalat tulis, buku kunci identifikasi Borror, et al., 1992.

Bahan yang digunakan adalah benih sawi hijau varietas Shinta yang diproduksi oleh PT. East-West Seed "Cap Panah Merah", dan pupuk kandang kotoran sapi sebagai pupuk dasar.

Penelitian dilaksanakan

melalui beberapa tahap mulai dari pembibitan sampai pada panen. Adapun tahap-tahap pelaksanaan penelitian sebagai berikut:

\section{Persiapan Lahan}

Persiapan lahan dilakukan selama 1 bulan, dimulai dari pembabatan rumput, pembuatan pelindungan berupa atap alangalang, pembuatan bedengan, dan penaburan pupuk dasar yaitu pupuk kandang dengan dosis 15 ton/ha (Neltriana, 2015) dan dibiarkan selama 2 minggu. Untuk jumlah pupuk kandang yang digunakan pada bedengan yang digunakan sebanyak $12 \mathrm{~kg}$ dengan luas bedengan 5 meter $x \quad 1,5$ meter. Perhitungan jumlah pupuk dasar yang digunakan sebagai berikut:

Dosis 15 ton $/ \mathrm{ha}=15.000 / 10.000$

$$
=1,5 \mathrm{~kg} / \mathrm{m}
$$

Luas bedengan $=5 \mathrm{~m} \mathrm{x} \mathrm{1,5} \mathrm{m}$

$$
=7,5 \mathrm{~m}
$$

Jadi yang dibutuhkan sebanyak :

Jumlah pupuk $=7,5 \mathrm{~m} \times 1,5 \mathrm{~m}$

$=11,25 \mathrm{~kg} /$ bedeng

Dibulatkan $\quad=12 \mathrm{~kg} / \mathrm{bedeng}$

\section{Pembibitan}

Pada awalnya benih yang telah disiapkan direndam dalam air bersih selama 30 menit untuk mempercepat perkecambahan. Setelah perendaman benih, selanjutkan dilakukan penaburan benih pada bedengan yang telah disiapkan untuk pembibitan.

\section{Penanaman}

Penanaman dilakukan setelah bibit tumbuh dan memiliki 3-4 helai daun. Bibit yang ditanam merupakan bibit yang sehat dan berukuran seragam yaitu memiliki 3-4 helai daun. Bibit ditanam sebatas leher akar, lalu tanah disekitar bibit dipadatkan dengan cara sedikit ditekan. 


\section{Pemeliharaan}

Pemeliharaan dilakukan dengan beberapa tahap mulai dari penyiraman dan penyiangan. Penyiraman dilakukan 1 kali sehari yaitu pada pagi hari. penyiraman tidak dilakukan jika hujan turun dan dilakukan dengan menggunakan sprayer jika tanaman masih kecil dan menggunakan gembor jika tanaman sudah mulai tumbuh besar. Penyiangan dilakukan saat tanaman berumur 10 hst dan pelaksanaannya dilakukan secara manual yaitu mencabut rumput atau gulma dengan menggunakan tangan.

\section{Pengamatan}

Pengamatan dilakukan dan dimulai saat tanaman berumur 7 hari setelah tanam (hst) sampai umur 51 hari (umur panen). Pengamatan dilakukan dengan cara mengambil hama-hama yang sedang menyerang tanaman sawi hijau dan di masukkan dalam botol koleksi untuk dilakukan pengamatan secara morfologi di laboratorium agronomi STIPER Petra Baliem Wamena dengan menggunakan lup dan mikroskop serta melakukan identifikasi dengan menggunakan buku kunci identifikasi dan mencocokkannya dengan jenis hama yang telah diketahui.

\section{Hasil Penelitian}

Berdasarkan hasil pengamatan di lapangan, saat tanaman sawi hijau berumur 2 minggu sampai dengan tiba panen hanya di temukan satu jenis hama yang menyerang. Hama yang teridentifikasi menginvasi tanaman sawi hijau yaitu ulat Tritip (Plutella xylostella L.) dapat dilihat pada gambar 2 . Berkurangnya hama yang menyerang pertanaman Sawi Hijau di mungkinkan karena pengaruh intensitas penyemprotan pestisida nabati yang diberikan sekali dalam seminggu mengakibatkan berkurangnya hama yang menginvasi tanaman sawi hijau. Ulat tritip (Plutella xylostella L.) yang teridentifikasi ditemukan masih dalam bentuk larva dengan ciri-ciri kapsul kepala berwarna kuning tua kehijauan, tubuh berwarna hijau kadang-kadang sedikit berwarna kuning pucat banyak di bawah daun.

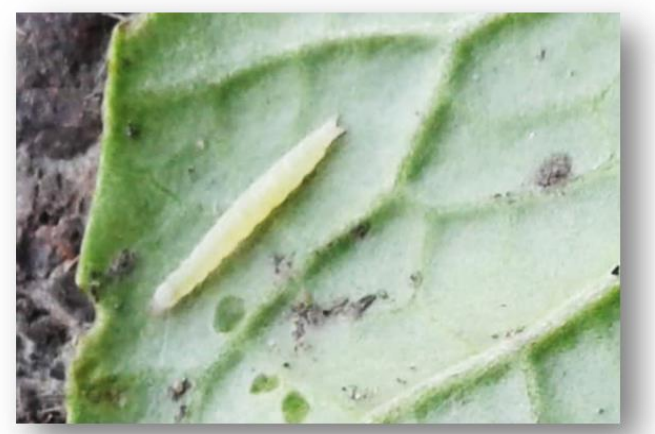

Gambar 1: Hama ulat/larva yang teridentifikasi menginvasi tanaman sawi hijau. 


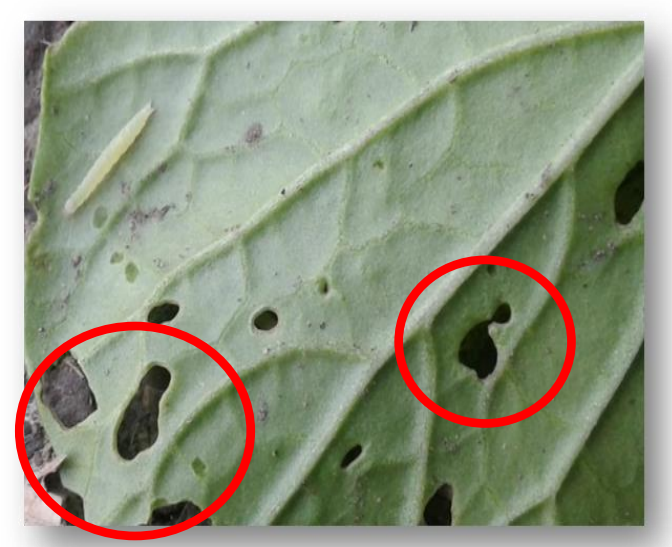

Gambar 2: Penampang luasan daun yang dikonsumsi ulat/larva.

\section{Pembahasan}

Tanaman sawi hijau merupakan tanaman hortikultura dengan hasil produksi utamanya berupa daun. Sawi mempunyai nilai ekonomi tinggi setelah kubis krop, kubis bunga, dan brokoli (Ndalewoa et al., 2012). Permasalahan utama dalam budidaya tanaman sawi hijau adalah adanya gangguan organisme pengganggu tanaman (OPT) berupa hama.

\section{Berdasarkan}

hasil pengamatan di lapangan, saat tanaman sawi hijau berumur 2 minggu sampai dengan umur 51 hari/masa panen hanya di temukan satu jenis hama yang menyerang. Jenis hama yang menyerang daun tanaman sawi hijau di lahan pertanian STKIP Kristen Wamena berupa larva/ulat (gambar 1) dengan ciri-ciri kapsul kepala berwarna kuning tua kehijauan, tubuh berwarna hijau dan sedikit berwarna kuning pucat, terdapat di bawah daun, berbentuk silindris. Berdasarkan hasil pengamatan secara morfologi dapat dikatakan bahwa jenis hama yang menyerang daun tanaman sawi hijau yang diteliti adalah ulat Tritip (Plutella xylostella L.).

Moriuti (1986) menyatakan, bahwa fase larva/ulat Tritip (Plutella xylostella L.) ditandai dengan kapsul kepala berwarna kuning tua kepucatan sampai kuning tua kehijauan, atau kadangkadang cokelat muda, bercorangcoreng dengan becak cokelat kehitaman dan kecokelatan. Tubuh berwarna hijau, kadang-kadang sedikit berwarna kuning pucat, jarang kuning pucat, kuning kemerah mudaan pucat, abu-abu muda. Larva $P$. xylostella terdiri atas empat instar. Hal ini dipertegas oleh Fanjri et al.,(2017) bahwa hama penting tanaman sawi hijau meliputi ulat Tritip, ulat Krop dan ulat Grayak.

Pada gambar 2, teramati bahwa rata-rata luasan daun yang dikonsumsi mencapai $5-7 \mathrm{~cm}^{2}$. Dari kerusakan daun tersebut dapat diidentifikasi bahwa larva yang menyerang memasuki instar larva kedua dan ketiga. Hal ini didukung oleh pernyataan Stapathi (1990), yang menyebutkan bahwa rata-rata luas daun yang dikonsumsi oleh larva instar kedua, ketiga dan keempat masing-masing adalah 5, 10 dan $7,5 \mathrm{~cm}^{2}$. 
Larva $P$. xylostella instar ketiga dan keempat makan permukaan bawah daun sawi akan meninggalkan lapisan epidermis bagian atas. Setelah jaringan daun membesar, lapisan epidermis pecah, sehingga terjadi lubang-lubang pada daun. Jika tingkat populasi larva tinggi, akan terjadi kerusakan berat pada tanaman sawi, sehingga yang tinggal hanya tulang-tulang daun sawi. Hal ini dapat menyebabkan gagal panen.

\section{Kesimpulan}

Hasil

penelitian menunjukkan bahwa hama yang menginvasi tanaman sawi hijau dalam penelitian ini yang berhasil ditemukan hanya ada satu yaitu Ulat Tritip (Plutella xylostella L.). Hama ditemukan dalam bentuk larva instar 2 sampai dengan 3 ditandai dengan adanya kerusakan daun dan dapat dilihat dari ciri-ciri morfologi larva Plutella xylostella $\mathrm{L}$.

\section{Saran}

Penelitian selanjutnya sebaiknya dilakukan pada beberapa lahan di beberapa wilayah yang ada di Wamena sehingga jenis hama yang ditemukan lebih bervariasi, pada akhirnya dapat memberikan informasi yang lebih banyak kepada petani tentang jenis hama yang dapat menyerang tanaman sawi hijau yang dibudidayakan di Wamena, Kabupaten Jajawijaya, Papua.

\section{Daftar Pustaka}

Borror DJ, Triplehorn CA, Johnson

NF. 1992. Pengenalan

Pelajaran Serangga. $6^{\text {th }}$ ed.

Partosoedjono

penerjemah. Yogyakarta

(ID):

UGM

Press.Terjemahan dari: $A n$

Introduction to the Study of Insects.

Direktorat Gizi Departemen

Kesehatan Republik

Indonesia. 1981. Daftar

Komposisi Bahan Makanan,

Bhatara Karya Aksara:

Jakarta.

Drost D \& Johnson M. 2010. Mustard in the garden. Utah State University Cooperative Extension Work. HG/Garden/2005-07pr.

Fajri, L., T. Heiriyani dan $H$. Susanti. 2017. Pengendalian hama ulat menggunakan larutan daun pepaya dalam peningkatan produksi sawi (brassica juncea l.). Ziraa'ah. 42(1): 69-79 hlm.

Haryanto, W., T. Suhartinidan E. Rahayu. 2003. Sawidan Selada Edisi Revisi, Penebar Swadaya: Jakarta.

Kalshoven LGE. 1981. The Pests of Crops inIndonesia. van der Laan PA (Rev. \& trans.) Rotschild GHL (Asssist.) PT Ichtiar Baru - van Hoeve, Jakarta. 
Moriuti, S. 1986. Taxonomic note on the diamondback moth. pp. 83-88. In. N.S. Talekar and T.D. Griggs (eds.). Diamondback Moth Management. Proceedings of the First International Workshop, Tainan, Taiwan, 11-15 March 1985. The Asian Vegeteble Research and Development Center, Shansua, Taiwan.

Nazaruddin. 1999. Budidaya dan Pengaturan Panen Sayuran Dataran Rendah, Penerbit Swadaya: Jakarta.

Ndalewoa, L. B., Anwar Daud dan Ruslan. 2012. Identifikasi klorpirifos dalam sawi hijau di pasar terong dan swalayan mtos Makassar. Fakultas Kesehatan Masyarakat. Universitas Hasanudin. Makassar.

Pracaya. 1999. Hama dan Penyakit Tanaman, Penebar Swadaya: Jakarta.
Rukmana, R. 2007. Bertanam Petsai dan Sawi. Kanisius. Yogyakarta.

Stapathi, C.R. 1990. Biology of diamondback moth, Plutellaxylostella (L.). Environment and Ecology, 8(2):784-785.

Wahyudi, T. 2004. Pengaruh Aplikasi Insektisida Piretroid Terhadap Tingkat Kerusakan Tanaman Populasi dan Keragaman Arthropoda Target dan Non Target Pada Tanaman Sawi. Skripsi. Fakultas Pertanian. Universitas Lampung. Bandar Lampung.

Wahyudi. 2010. Petunjuk Praktis Bertanam Sayuran. Agromedia Pustaka. Jakarta. 